REPORTS OF MORPHOLOGY
$\begin{gathered}\text { Official Journal of the Scientific Society of Anatomists, } \\ \text { Histologists, Embryologists and Topographic Anatomists } \\ \text { of Ukraine } \\ \text { journal homepage: https://morphology-journal.com }\end{gathered}$

\title{
Change of anthropometric indicators in qualified young women volleyball players during the annual training macrocycle
}

Sarafyniuk L.A. ${ }^{1}$, Khapitska O.P. ${ }^{1}$, Sarafyniuk P.V. ${ }^{2}$, Koliadenko S.V. ${ }^{1}$, Cherkasova L.A. ${ }^{3}$

${ }^{1}$ National Pirogov Memoria Medical University, Vinnytsya, Ukraine

${ }^{2}$ Vinnitsia State Mykhailo Kotsyubynskyi Pedagogical University, Vinnytsya, Ukraine

${ }^{3}$ Bogomolets National Medical University, Kyiv, Ukraine

ARTICLEINFO
Received: 10 December, 2019
Accepted: 9 January, 2020

UDC: $572.5: 796.325-05: 611.018 .2$

\section{CORRESPONDING AUTHOR}

e-mail: Isarafinyuk@gmail.com Sarafyniuk L.A.
Determining the indicators of the external body structure, which are inherent in highly qualified athletes of a particular sport during the annual training macrocycle, can be reliable markers in sports selection. The aim of the work is to determine the differences of anthropometric dimensions in qualified young women volleyball players at the beginning of the preparatory period and at the end of the competitive period of the annual training cycle. We examined 36 young women volleyball players of the section of sports improvement of National Pirogov Memorial Medical University, Vinnytsya and the women's volleyball team of the Super League of Ukraine "Bilozgar - Medical University". All volleyball players belonged to a juvenile age (from 16 to 20 years) and had a high level of sportsmanship. We conducted two surveys of volleyball players during the 2018-2019 study year: the first - in September 2018, which corresponded to the beginning of the preparatory period of the annual training cycle; the second - in May 2019, which was at the end of the competitive period of the annual training cycle. Anthropometric measurement was performed by the method of V.V. Bunak (1941). The analysis of the obtained results was performed in the license package "Statistica 5.5" using non-parametric methods of evaluation of indicators. At the end of the competition period, compared to the preparatory training period, volleyball players of high level of sportsmanship in adolescence showed a statistically significant decrease in body weight with a significant increase in shoulder width, chest circumference on inspiration, thighs and crus in the upper third, and a tendency to larger values of the height of the suprasternal and shoulder points, torso length and transverse mid-chest diameter. Certain somatometric features of volleyball players can be considered from two aspects: first, as a consequence of qualified prognostic sports selection, and secondly, as a result of training and competitive sports activities. Analysis of external body parameters in volleyball players during the annual macrocycle can be used as criteria for ascertaining sports selection, because when selecting at the stages of advanced specialization it is necessary to identify athletes capable of achieving high sports results, effective sports improvement in subsequent stages of training.

Keywords: anthropometry, young women volleyball players, juvenile age, preparatory and competitive periods, annual macrocycle.

\section{Introduction}

The modern methodology of sports selection [3] of volleyball players is based on sports-pedagogical concepts [15], which require the use of constitutional parameters of athletes as prognostic markers [1, 2, 19, 24, 26], indicators of motor and technical fitness $[4,5]$, biological inclinations of motor abilities $[9,11]$ and their ratio is determined, which creates the potential for an individual to achieve a high sports result. Scientists have proven the viability of using genetic markers $[6,8,10,16,17,19]$ to diagnose the development of morpho-functional traits and motor skills of athletes. For all the multiplicity and ambiguity of these characteristics, their genetic component, the degree of determination and variability under the influence of phenotypic influences, remains outside the scope of research. Determination of model characteristics of total and partial body sizes, which are inherent in highly qualified 
athletes of a particular sport, can be considered when conducting sports prognostic and ascertaining sports selection.

There was a significant difference in the size of anthropometric body size in women volleyball players, compared with girls who did not play sports [20, 21, 23, 26]. But, from our point of view, it was interesting to get an answer to the question of whether somatometric dimensions change in qualified women volleyball players under the influence of sports during the annual macrocycle and what anthropometric indicators can be used as criteria for ascertaining sports selection in women's volleyball.

The aim of the work is to determine the differences of anthropometric dimensions in qualified women volleyball players at the beginning of the preparatory period and at the end of the competitive period of the annual training cycle.

\section{Materials and methods}

We examined 36 young women volleyball players of the section of sports improvement of National Pirogov Memorial Medical University, Vinnytsya and the women's volleyball team of the Super League of Ukraine "Bilozgar - Medical University". All volleyball players belonged to a young age (from 16 to 20 years) and had a high level of sportsmanship. By sports categories, the distribution was as follows: 2nd adult category had 9 people $(25.0 \%)$, 1st adult - 18 people $(50.0 \%)$, candidates for masters of sports - 5 people (13.9\%), masters of sports - 4 people (11.1\%). The average sports experience was $5.65 \pm 1.35$ years. The coach of both teams was the Master of Sports of Ukraine, Ph.D., Associate Professor Yakusheva Y.I. The annual training cycle in both teams (student and professional) had a single-cycle structure and consisted of three periods: preparatory, which lasted about three months (August-October), competitive, which lasted for seven months (late October-early June) and a transition period of two months. We conducted two surveys of volleyball players during the 2018-2019 study year: the first - in September 2018, which corresponded to the beginning of the preparatory period of the annual training cycle; the second - in May 2019, which was at the end of the competitive period of the annual training cycle.

The beginning of the preparatory period of the annual training cycle corresponded to the stage of general training, the main task of which was to form the basis for the development of sports form. In the competitive period stabilization of a sports form at the expense of integral preparation is carried out. The main tasks of this period were to increase the achieved level of special training and achieve high sports results in competitions [14].

Anthropometric measurement was performed by the method of V.V. Bunak [7]. The analysis of the obtained results was carried out with the help of the licensed program "Statistica 5.5" using non-parametric methods of evaluation of indicators. The significance of the difference between the values between the independent quantitative indicators was determined using the Mann-Whitney U-test.

\section{Results}

After comparing the anthropometric dimensions of volleyball players at the beginning of the training period and at the end of the competitive period of the annual training cycle, we found that in volleyball players such total dimensions as length and body surface area do not change significantly. We noted a significant decrease $(p<0.05)$ in body weight at the end of the competitive period (Table 1).

It was found that some longitudinal body sizes during the annual training cycle in adolescent volleyball players have a positive dynamic (Table 2). It is established that female athletes at the end of the year tend to have higher values of the height of the suprasternal and shoulder points. The height of the finger, pubic and trochanter points during the annual training cycle of youth volleyball players does not change significantly.

In volleyball players, the length of the arm and leg does not experience statistically significant differences during the annual training cycle, and the length of the torso has a pronounced tendency to greater values at the end of the competition period (see Table 2).

Analyzing the features of girth, transverse and anteriorposterior torso dimensions in volleyball players in different periods of the annual training cycle, it should be noted that in volleyball players waist and chest girth on exhalation and at rest, lower chest diameter, anterior-posterior midthoracic diameter pelvis do not undergo significant changes during the annual training macrocycle (Table 3).

Chest girth on inspiration and shoulder width in volleyball players were statistically significantly greater at the end of the competition period than at the beginning of

Table 1. Total body size of young women volleyball players in different periods of the annual training cycle $(\mathrm{M} \pm \sigma)$.

\begin{tabular}{|c|c|c|c|}
\hline Indicators & $\begin{array}{c}\text { Preparatory } \\
\text { period }\end{array}$ & $\begin{array}{c}\text { Competitive } \\
\text { period }\end{array}$ & $\mathrm{p}$ \\
\hline Body weight $(\mathrm{kg})$ & $66.89 \pm 6.36$ & $64.16 \pm 6.48$ & $<0.05$ \\
\hline Body length $(\mathrm{cm})$ & $174.3 \pm 5.73$ & $175.7 \pm 3.26$ & $>0.05$ \\
\hline Body surface area $\left(\mathrm{m}^{2}\right)$ & $1.777 \pm 0.140$ & $1.765 \pm 0.130$ & $>0.05$ \\
\hline
\end{tabular}

Table 2. Features of longitudinal body dimensions in young women volleyball players in different periods of the annual training cycle $(\mathrm{M} \pm \sigma, \mathrm{cm})$.

\begin{tabular}{|c|c|c|c|}
\hline Anthropometric dimensions & $\begin{array}{c}\text { Preparatory } \\
\text { period }\end{array}$ & $\begin{array}{c}\text { Competitive } \\
\text { period }\end{array}$ & $\mathrm{p}$ \\
\hline Height of the suprasternal point & $142.5 \pm 6.6$ & $143.5 \pm 3.2$ & $=0.068$ \\
\hline Pubic point height & $90.91 \pm 4.51$ & $91.31 \pm 5.06$ & $>0.05$ \\
\hline Height of the shoulder point & $145.7 \pm 6.4$ & $147.1 \pm 4.3$ & $=0.064$ \\
\hline Height of the finger point & $67.71 \pm 4.92$ & $67.84 \pm 3.19$ & $>0.05$ \\
\hline Height of the trochanter points & $92.25 \pm 5.71$ & $92.52 \pm 4.28$ & $>0.05$ \\
\hline Arm length & $79.21 \pm 3.77$ & $80.06 \pm 1.38$ & $>0.05$ \\
\hline Body length & $54.19 \pm 4.25$ & $55.75 \pm 1.27$ & $=0.056$ \\
\hline Leg length & $91.36 \pm 4.51$ & $91.37 \pm 2.48$ & $>0.05$ \\
\hline
\end{tabular}


Table 3. Features of girth, transverse and anterior-posterior torso sizes in young women volleyball players in different periods of the annual training cycle $(\mathrm{M} \pm \sigma, \mathrm{cm})$.

\begin{tabular}{|c|c|c|c|}
\hline Anthropometric dimensions & $\begin{array}{c}\text { Preparatory } \\
\text { period }\end{array}$ & $\begin{array}{c}\text { Competitive } \\
\text { period }\end{array}$ & $\mathrm{p}$ \\
\hline Waist circumference & $70.22 \pm 5.01$ & $69.83 \pm 4.28$ & $>0.05$ \\
\hline Chest girth on inhalation & $95.05 \pm 5.99$ & $97.47 \pm 7.14$ & $<0.05$ \\
\hline Chest girth on exhalation & $85.95 \pm 6.34$ & $86.41 \pm 6.37$ & $>0.05$ \\
\hline Chest girth at rest & $89.95 \pm 6.29$ & $90.07 \pm 5.60$ & $>0.05$ \\
\hline Transverse middle thoracic & $26.61 \pm 2.55$ & $27.94 \pm 1.48$ & $=0.056$ \\
\hline Transverse lower thoracic & $23.68 \pm 2.31$ & $24.15 \pm 3.38$ & $>0.05$ \\
\hline Anterior-posterior mid-thoracic & $18.17 \pm 1.02$ & $18.02 \pm 1.51$ & $>0.05$ \\
\hline Shoulder width & $36.12 \pm 1.16$ & $37.94 \pm 1.66$ & $<0.05$ \\
\hline Interspinous distance & $25.49 \pm 2.06$ & $24.84 \pm 1.77$ & $>0.05$ \\
\hline Intercristal distance & $29.59 \pm 2.14$ & $29.58 \pm 1.65$ & $>0.05$ \\
\hline Intertrochanteric distance & $32.85 \pm 2.02$ & $33.15 \pm 1.36$ & $>0.05$ \\
\hline External conjugate & $19.26 \pm 1.76$ & $19.27 \pm 1.05$ & $>0.05$ \\
\hline
\end{tabular}

Table 4. Features of the width of the distal epiphyses of the limb segments in young women volleyball players in different periods of the annual training cycle $(\mathrm{M} \pm \sigma, \mathrm{cm})$.

\begin{tabular}{|c|c|c|c|}
\hline Anthropometric dimensions & $\begin{array}{c}\text { Preparatory } \\
\text { period }\end{array}$ & $\begin{array}{c}\text { Competitive } \\
\text { period }\end{array}$ & $\mathrm{p}$ \\
\hline Shoulder epiphysis & $6.482 \pm 0.410$ & $6.564 \pm 0.410$ & $>0.05$ \\
\hline Forearm epiphysis & $5.324 \pm 0.331$ & $5.383 \pm 0.301$ & $>0.05$ \\
\hline Thigh epiphysis & $8.743 \pm 0.832$ & $8.794 \pm 0.512$ & $>0.05$ \\
\hline Crus epiphysis & $6.842 \pm 0.511$ & $6.960 \pm 0.423$ & $>0.05$ \\
\hline
\end{tabular}

Table 5. Features of circumferential sizes of extremities in young women volleyball players in different periods of an annual training cycle $(\mathrm{M} \pm \sigma, \mathrm{cm})$.

\begin{tabular}{|c|c|c|c|}
\hline Anthropometric dimensions & $\begin{array}{c}\text { Preparatory } \\
\text { period }\end{array}$ & $\begin{array}{c}\text { Competitive } \\
\text { period }\end{array}$ & $\mathrm{p}$ \\
\hline Shoulder in a tense state & $28.05 \pm 2.37$ & $29.52 \pm 1.53$ & $<0.05$ \\
\hline Shoulder not in a tense state & $26.53 \pm 2.48$ & $26.73 \pm 2.50$ & $>0.05$ \\
\hline Forearms in the upper third & $23.98 \pm 1.02$ & $23.86 \pm 1.61$ & $>0.05$ \\
\hline Forearms in the lower third & $15.74 \pm 0.86$ & $15.83 \pm 1.14$ & $>0.05$ \\
\hline Hands & $18.89 \pm 0.77$ & $18.93 \pm 1.14$ & $>0.05$ \\
\hline Foots & $23.05 \pm 1.13$ & $23.39 \pm 1.21$ & $>0.05$ \\
\hline Thigh & $54.22 \pm 3.62$ & $57.88 \pm 3.15$ & $<0.05$ \\
\hline Crus in the upper third & $36.21 \pm 2.54$ & $37.18 \pm 1.90$ & $<0.05$ \\
\hline Crus in the lower third & $22.89 \pm 2.45$ & $22.82 \pm 1.56$ & $>0.05$ \\
\hline
\end{tabular}

the training period (in both cases $p<0.05$ ). The transverse mean thoracic diameter tends to increase during the annual macrocycle $(p=0.056)$ (see Table 3 ).

We found that volleyball players during the annual training macrocycle did not experience significant changes in the size of the transverse dimensions of the diaphysis of large tubular bones (Table 4).

It was found that volleyball players at the end of the competitive period of the training cycle had a significant increase in the girth of the tense shoulder, thigh and crus in the upper third (in all cases $p<0.05$ ) (Table 5). The girth of other segments of the upper and lower extremities do not undergo significant changes during the annual training macrocycle in volleyball players of high skill level of adolescence.

\section{Discussion}

An important social problem is the correct assessment of the potential of each person and the optimal use of his physical abilities. Specialization in sports should be based on the adequacy of human biological capabilities to the demands of sports activities. Adequate phenotypic sports orientation will avoid many adverse consequences from the wrong choice of profile of sports specialization. New tasks of sports selection are reduced to disclosure of constitutional features of reactivity of an organism and character of its growth and development on external diagnostically significant signs. The results of research $[10,16,23]$ indicate the possibility of predicting the prospects of young athletes on anthropometric traits, which due to genetic conditionality change relatively little.

The length, weight and surface area of the body are signs that must be considered when conducting prognostic and ascertaining sports selection in volleyball [21]. In our previous studies at the beginning of the annual training macrocycle, when comparing anthropometric data between groups of athletes and controls, it was found that length, weight, body surface area, all longitudinal body dimensions, chest and limb circumference, distal epiphyseal width, transverse median and lower thoracic size, anteriorposterior mid-thoracic diameter, intertrochanteric and intercristal distances in qualified volleyball players are significantly larger than in young women who do not play sports [22]. During the annual macrocycle, we did not find significant changes in the length and surface area of volleyball players, although the average group values of body length in volleyball players at the end of the year are higher. Significant weight loss at the end of the competition period can be explained by more intense physical and psycho-emotional stress in volleyball players at the end of the annual macrocycle. When analyzing the dynamics of the longitudinal dimensions of the body, our attention was drawn to a pronounced tendency to increase the length of the torso and the height of the suprasternal and shoulder points, which can be explained by the ontogenetic features of the body of young women. In the research of B. O. Nikityuk it was proved that the closure of the epiphyseal zones of growth of tubular bones in the body of young women occurs in 16-17 years [18]. The exact mechanisms of regulation of processes occurring at the level of epiphyseal germ plates are not known. Among the factors influencing these processes are genetic, vascular, hormonal and biomechanical [13]. In the middle of the XIX century the regularity of influence of the mechanical factor on longitudinal growth of bones was described (HeuterVolkmann's law). The essence of this law is that 
longitudinal growth is slowed down by excessive mechanical stress, which has a compressive effect, and conversely, moderate exercise, which has a decompressive effect, stimulates growth processes [12]. Our results on the longitudinal growth of the upper and lower extremities during the annual training cycle does not contradict the previous study. At the same time, the established positive growth dynamics of torso length can be explained by the fact that during the adolescent period of ontogenesis there are processes of longitudinal trunk growth [25], most likely due to the height of vertebral bodies and increasing intervertebral disc thickness.

Thus, the analysis of external body parameters in volleyball players during the annual macrocycle can be used as criteria for ascertaining sports selection, because the selection at the stages of advanced specialization must identify athletes capable of achieving high sports results, effective sports improvement in subsequent stages of longterm training. This problem can be solved only on the basis

\section{References}

[1]Adhikari, A., Nahida, P., Islam, R. N., \& Kitab, A. (2014). Importance of Anthropometric Characteristics in Athletic Performance from the Perspective of Bangladeshi National Level Athletes' Performance and Body Type. American Journal of Sports Science and Medicine, 2(4), 123-127. doi: 10.12691/ajssm-24-1D

[2] Bacciotti, S., Baxter-Jones, A., Gaya, A., \& Maia, J. (2018). Body physique and proportionality of Brazilian female artistic gymnasts. J. Sports Sci., 36(7), 749-756. doi: 10.1080/ 02640414.2017.1340655

[3] Barth, M., Emrich, E., \& Daumann, F. (2018). Approaches and methods used for measuring organizational performance in national sport governing bodies from 1986 to 2014. A systematized review. Current Issues in Sport Science, 3, 122. doi: $10.15203 / C I S S \_2018.010$

[4] Boichuk, R., lermakov, S., \& Nosko, M. (2017). Pedagogical conditions of motor training of junior volleyball players during the initial stage. Journal of Physical Education and Sport, 17(1), 327-334. doi:10.7752/jpes.2017.01048

[5] Boichuk, R., lermakov, S., Nosko, M., Kovtsun, V. \& Nosko, Y. (2017). Original Article Influence of motor coordination indicators on efficiency of game activity of volleyball players at the stage of specialized basic training. Journal of Physical Education and Sport, 17(4), 2632-2637. doi: 10.7752/jpes.2017.04301

[6] Bouchard, C. (2011). Overcoming barriers to progress in exercise genomics. Exerc Sport Sci Rev., 39, 212-217.

[7] Bunak, V. V. (1941). Anthropometry: a practicalcourse. M.: Uchpedgiz.

[8] Di Rienzo, F., Hoyek, N., Collet, C., \& Guillot, A. (2014). Physiological changes in response to apnea impact the timing of motor representations: a preliminary study. Behavioral and Brain Functions., 10(1), 15. doi: 10.1186/1744-9081-10-15

[9] Freitas, A. S., Figueiredo, A. J., deFreitas, A. L., Rodrigues, V. D., daCunha, A. A., Deusdará, F. F., .. \& \& Silva, M. J. (2014). Biological Maturation, Body Morphology and Physical Performance in 816 year-old obese girls from Montes Claros - MG. J. Hum. Kinet., 43, 169-176. doi: 10.2478/hukin-2014-0102

[10] Guilherme, J. P., Tritto, A., North, K. N., Lancha, J. A. H., \& Artioli, G. G. (2014). Genetics and sport performance: current challenges and directions to the future. Rev Bras Educ Fis of a comprehensive analysis of morphological, functional and mental characteristics of athletes, their adaptive capacity, response to increased training and competitive loads.

\section{Conclusions}

1. At the end of the competitive period, compared to the preparatory training period, qualified young women volleyball players showed a significant decrease in body weight with a statistically significant increase in shoulder width, chest girth on inspiration, thighs and crus in the upper third and a tendency to greater values of chest and suprasternal and shoulder points, torso length and transverse mid-sternal diameter.

2. In order to improve the system of sports orientation it is necessary to conduct a comprehensive anthropometric examination after each stage of training athletes, so in further research it is necessary to develop a set of anthroposomatotypological features that can be used as criteria for sports selection in women's volleyball.

Esporte, 28(1), 177-193.

[11] Guillot, A., Moschberger, K., \& Collet, C. (2013). Coupling movement with imagery as a new perspective for motor imagery practice. Behav Brain Funct., 9, 8. doi: 10.1186/1744-9081-9-8

[12] Hefti, F., Freuler, F., Hinchliffe, R., \& Brunner, R. (2007). Pediatric Orthopedics in Practice. New York: Springer.

[13] Korzh, N. A., Khmyzov, S. A., Korolkov, A. I., \& Ershov, D. V. (2013). The method of temporary blocking of growth zones in the treatment of lower limb deformities in children (literature review). Orthopedics, Traumatology and Prosthetics, 2, 114-121.

[14] Kostyukevich, V. M. (2014). Theory and methodology of sports training (on the example of team play sports). Vinnytsia: Glider.

[15] Kozina, Zh. L., Prusik, Krzysztof, \& Prusik, Katarzyna (2015). The concept of individual approach in sport. Pedagogy of Physical Culture and Sports, 19(3), 28-36. doi: 10.15561/ 18189172.2015.0305

[16] Lippi, G., Maffulli, N., \& Longo, U. G. (2009). Genetics and sports. British Medical Bulletin, 93(1), 27-47. doi: 10.1093/ bmb/ldp007

[17] Liu, J., Lewis, G., \& Evans, L. (2013). Understanding Aggressive Behavior Across the Life Span. J. Psychiatr. Ment. Health Nurs., 20(2), 156-168. doi: 10.1111/j.1365-2850.2012.01902.x

[18] Nikityuk, B. A. (1997). Biotechnological and valeological aspects of human anatomy. Vinnitsa - Moscow.

[19] Pastuszak, A., Busko, K., \& Kalka, E. (2016). Somatotype and body composition of volleyball players and untrained female students - reference group for comparison in sport. Anthropological Review, 79(4), 461-470.

[20] Sarafinyuk, L. A. Fomina, L. V., Khavtur, V. O., Khapitska, O. P., \& Stefanenko, I. S (2018). Features of total body sizes and anthropometric sizes in volleyball players of mesomorphic somatotype. Reports of Morphology, 24(3), 32-36. doi: 10.31393/ morphology-journal-2018-24(3)-05

[21] Sarafinyuk, L. A., \& Yakusheva, Y. I. (2015). Differences in longitudinal body sizes in volleyball players of different roles. Actual Questions of Medical Science and Practice, 82(2), 170176.

[22] Sarafinyuk, L. A., Boguslavska, V., \& Kotsyuruba, V. (2019). Peculiarities of Anthropometric Dimensions of Qualified Volleyballists of Youth Age at the Beginning of the Preparatory 
Period of the Annual Training Cycle. Physical Culture, Sports and Health of the Nation, 8(27), 206-211. doi: 10.31652/20715285-2019-5(24)-206-211

[23] Sarafyniuk, L. A., Pivtorak, V. I., Khavtur, V. O., Fedoniuk, L. la., \& Khapitska, O. P. (2018). Peculiarities of the chest"s size in female volleyball players of different constitutional types. Biomedical and Biosocial Anthropology, 33, 47-53. doi: 10.31393/bba33-2018-08

[24] Stanković, D., Pavlović, R., Petković, E., Raković, A., \& Puletić,
M. (2018). The somatotypes and body composition of elite track and field athletes and swimmers. International Journal of Sports Science, 8(3), 67-77. doi: 10.5923/ j.sports. 20180803.01

[25] Wenger, D. R., \& Rang, M. (1993). The art and practice of children's orthopaedics. New York : Raven Press.

[26] Yakusheva, Y. I., \& Sarafinyuk, L. A. (2014). Features of total and separate partial anthropometric sizes in volleyball players of adolescence. Reports of Morphology, 20(2), 473-475.

\section{ЗМІНА АНТРОПОМЕТРИЧНИХ ПОКАЗНИКІВ У КВАЛІФІКОВАНИХ ВОЛЕЙБОЛІСТОК ЮНАЦЬКОГО ВІКУ ПРОТЯГОМ РІЧНОГО ТРЕНУВАЛЬНОГО МАКРОЦИКЛУ \\ Сарафинюк Л.А., Хапіцька О.П., Сарафинюк П.В., Коляденко С.В., Черкасова Л.А.}

Визначення показників зовнішньої будови тіла, які притаманні висококваліфрікованим спортсменам окремого виду спорту протягом річного тренувального макроциклу, можуть виступати надійними маркерами при проведенні спортивного відбору. Мета роботи - визначити відмінності антропометричних розмірів у кваліфікованих волейболісток на початку підготовчого періоду та у кінці змагального періоду річного тренувального циклу. Нами було обстежено 36 волейболісток секції спортивного вдосконалення Вінницького національного медичного університету ім. М.І. Пирогова та жіночої волейбольної команди Супер ліги України "Білозгар - Медуніверситет". Всі волейболістки належали до юнацького віку (від 16 до 20 років) та мали високий рівень спортивної майстерності. Нами було проведено два обстеження волейболісток протягом 2018-2019 навчального року: перше - у вересні 2018 р., що відповідало початку підготовчого періоду річного тренувального циклу; друге - у травні 2019 р., що було у кінці змагального періоду річного тренувального циклу. Антропометричне вимірювання проводили за методом В.В. Бунака (1941). Аналіз отриманих результатів проведено у ліцензійному пакеті "Statistica 5.5" з використанням непараметричних методів оцінки показників. Виявлено у кінці змагального періоду, порівняно з підготовчим тренувальним періодом, у волейболісток високого рівня спортивної майстерності юнацького віку статистично значуще зменшення маси тіла з одночасним достовірним збільшенням ширини плечей, обхватів грудної клітки на вдиху, стегна та гомілки у верхній третині, а також виявлена тенденція до більших значень висоти надгруднинної та плечової точок, довжини тулуба та поперечного середньогрудного діаметра. Визначені соматометричні особливості волейболісток можна розглядати з двох аспектів: по-перше, як наслідок кваліфікованого прогностичного спортивного відбору; по-друге, як результат тренувальнозмагальної спортивної діяльності. Аналіз зовнішніх параметрів тіла у волейболісток протягом річного макроциклу можна використовувати як критерії констатуючого спортивного відбору, тому що при відборі на етапах поглибленої спеціалізації необхідно виявляти спортсменів, здатних до досягнення високих спортивних результатів, ефективного спортивного вдосконалення на наступних етапах багаторічної підготовки.

Ключові слова: антропометрія, волейболістки, юнацький вік, підготовчий та змагальний періоди, річний макроцикл.

\section{ИЗМЕНЕНИЕ АНТРОПОМЕТРИЧЕСКИХ ПОКАЗАТЕЛЕЙ У КВАЛИФИЦИРОВАННЫХ ВОЛЕЙБОЛИСТОК ЮНОШЕСКОГО ВОЗРАСТА В ТЕЧЕНИЕ ГОДИЧНОГО ТРЕНИРОВОЧНОГО МАКРОЦИКЛА \\ Сарафинюк Л.А., Хапицкая О.П., Сарафинюк П.В., Коляденко С.В., Черкасова Л.А.}

Определение показателей внешнего строения тела, которые присущи высококвалифицированным спортсменам отдельного вида спорта в течение годового тренировочного макроцикла, могут выступать надежными маркерами при проведении спортивного отбора. Цель работы - определить различия антропометрических размеров у квалифицированных волейболисток в начале подготовительного периода и в конце соревновательного периода годичного тренировочного цикла. Нами было обследовано 36 волейболисток секции спортивного усовершенствования Винницкого национального медицинского университета им. Н.И.Пирогова и женской волейбольной команды Супер лиги Украины "Билозгар Медуниверситет". Все волейболистки принадлежали к юношескому возрасту (от 16 до 20 лет) и имели высокий уровень спортивного мастерства. Нами было проведено два обследования волейболисток в течение 2018-2019 учебного года: первое - в сентябре 2018, что соответствовало началу подготовительного периода годичного тренировочного цикла; второе - в мае 2019, что было в конце соревновательного периода годичного тренировочного цикла. Антропометрическое измерения проводили по методу В.В. Бунака (1941). Анализ полученных результатов проведен в лицензионном пакете "Statistica 5.5" с использованием непараметрических методов оценки показателей. Выявлено в конце соревновательного периода по сравнению с подготовительным тренировочным периодом, у волейболисток высокого уровня спортивного мастерства юношеского возраста статистически значимое уменьшение массы тела с одновременным достоверным увеличением ширины плеч, обхватов грудной клетки на вдохе, бедра и голени в верхней трети, а также выявлена тенденция к большим значениям высоты надгрудинной и плечевой точек, длины туловища и поперечного среднегрудного диаметра. Определенные соматометрические особенности волейболисток можно рассматривать с двух аспектов: во-первых, как следствие квалифицированного прогностического спортивного отбора; во-вторых, как результат тренировочносоревновательной спортивной деятельности. Анализ внешних параметров тела у волейболисток в течение годичного макроцикла можно использовать в качестве критериев констатирующего спортивного отбора, так как при отборе на этапах углубленной специализации необходимо выявлять спортсменов, способных к достижению высоких спортивных результатов, эффрективного спортивного совершенствования на следующих этапах многолетней подготовки.

Ключевые слова: антропометрия, волейболистки, юношеский возраст, подготовительный и соревновательный периоды, годовой макроцикл. 